\title{
Plasminogen Activator Inhibitor-1 and Tissue-Plasminogen Activator in Minority Adolescents with Type 2 Diabetes and Obesity
}

\author{
VATCHARAPAN UMPAICHITRA, M. MAHMOOD HUSSAIN, AND SALVADOR CASTELLS \\ Pediatric Endocrinology [V.U., S.C.], Department of Pediatrics, The Brookdale University Hospital and \\ Medical Center/State University of New York Health Science Center at Brooklyn (SUNY Downstate), \\ Brooklyn, NY 11212; Department of Anatomy and Cell Biology [M.M.H.], SUNY Downstate, Brooklyn, NY \\ 11203; and Pediatric Endocrinology, Department of Pediatrics, SUNY Downstate, Brooklyn, NY 11203
}

\begin{abstract}
Increased plasminogen activator inhibitor-1 (PAI-1) and decreased tissue-plasminogen activator (t-PA) activities lead to impaired fibrinolysis, which is critical for cardiovascular disease. We studied these hemostatic factors at fasting state and after an oral fat load in 12 type 2 diabetic and 17 nondiabetic obese adolescents, matched for age, sex, body mass index, and sexual maturation. Plasma PAI-1, t-PA, and glucose as well as serum C-peptide, insulin, total cholesterol, triglyceride, and HDL and LDL cholesterol levels were measured at $0,2,4$, and $6 \mathrm{~h}$ after the fat load. Metabolic responses were expressed as the area under the curve (AUC). PAI-1 activities were significantly greater in patients than in control subjects [fasting, $23.4 \pm 2.6$ versus $12.9 \pm 2.0 \mathrm{U} / \mathrm{mL}(p<0.004)$; AUC, $101.7 \pm 12.1$ versus $\left.57.6 \pm 6.5 \mathrm{U} \cdot \mathrm{h}^{-1} \cdot \mathrm{mL}^{-1}(p<0.003)\right]$. Fasting t-PA activities were significantly lower in the patients than in the control subjects $(0.8 \pm 0.3$ versus $6.5 \pm 2.7 \mathrm{U} / \mathrm{mL} ; p<$ 0.001). Triglyceride was the only lipid parameter that was significantly different in the patients than in the control subjects [fasting, $1.5 \pm 0.2$ versus $0.9 \pm 0.1 \mathrm{mM}(p<0.05)$; AUC, $15.7 \pm 2.9$ versus $\left.7.9 \pm 0.6 \mathrm{mmol} \cdot \mathrm{h}^{-1} \cdot \mathrm{L}^{-1}(p<0.02)\right]$. The PAI-1 activities
\end{abstract}

\section{ABSTRACT}

decreased significantly during the loading tests $(p<0.0001)$, whereas the t-PA activities did not change. Insulin resistance estimated by the homeostasis model assessment was greater in the patients than in the control subjects $(14.4 \pm 2.8$ versus $4.6 \pm 0.7$; $p<0.0001)$. We conclude that elevated PAI-1 and diminished t-PA activities, suggestive of suppressed fibrinolysis, are present in our adolescents with type 2 diabetes; adding another risk factor for cardiovascular disease and acute high fat load does not further negatively affect this suppressed fibrinolysis. (Pediatr Res 58: 483487, 2005)

Abbreviations
AUC, area under the curve
BMI, body mass index
CVD, cardiovascular disease
HOMA, homeostasis model assessment
PAI-1 plasminogen activator inhibitor-1
t-PA, tissue-plasminogen activator

Insulin resistance followed by absolute or relative insulin deficiency is a known course of type 2 diabetes development $(1,2)$. Type 2 diabetes, obesity, dyslipidemia, and abnormal factors related to blood clotting are risk factors of cardiovascular disease (CVD) and are often seen in patients with insulin resistance (2-7). Tissue-plasminogen activator (t-PA) initiates fibrinolysis. Plasminogen activator inhibitor-1 (PAI-1) binds rapidly to t-PA and has an inhibitory activity against t-PA (6). As a result, abnormal PAI-1 and/or t-PA activities contribute to a thrombotic tendency (6). Elevated plasma PAI-1 activities and antigens have been reported in adults with type 1 diabetes, type 2 diabetes, and obesity as well as in children with type 1 diabetes and obesity

Received August 5, 2004; accepted November 30, 2004.

Correspondence: Vatcharapan Umpaichitra, M.D., Pediatric Endocrinology, Department of Pediatrics, The Brookdale University Hospital and Medical Center, One Brookdale Plaza, Room 300 CHC, Brooklyn, NY 11212; e-mail: vumpaich@brookdale.edu.

DOI: 10.1203/01.PDR.0000164307.92308.09
(8-20). Elevated plasma t-PA antigens have been reported in adults with type 1 diabetes, type 2 diabetes, and obesity as well as in children with type 1 diabetes and obesity $(8,13,19,21)$. Decreased plasma t-PA activities and a decreased capacity of endothelial cells to secret t-PA in response to a fibrinolytic stimulus were also reported in adults with diabetes $(7,14,22)$. Normal PAI-1 and t-PA antigens, however, have been shown in children and adults with type 1 diabetes $(17,19)$. Because there are few data about PAI-1 and t-PA in children and adolescents with type 2 diabetes, there is a continuing increase in type 2 diabetes and obesity in this population, which is thought to be due to high caloric intake and sedentary life style (especially in minority groups) (23-25), and CVD begins in childhood $(26,27)$, we studied the PAI-1 and t-PA activities at fasting state as well as an impact of a fat load assigned to simulate the fat content of a high-fat, fast-food meal (28) to these critical factors in minority adolescents with type 2 diabetes and obesity. 


\section{METHODS}

Study groups. Twelve type 2 diabetic obese and 17 nondiabetic obese adolescents (predominantly blacks) participated in our study. All type 2 diabetic patients had 1) negative antibodies to glutamic acid decarboxylase, islet cell, and insulin and 2) fasting serum C-peptide levels $>0.2 \mathrm{nmol} / \mathrm{L}$ (29). Mean duration of diabetes was $7.1 \pm 2.5$ mo. All nondiabetic subjects had fasting glucose levels $<6.1 \mathrm{mM}$ (1) and normal $\mathrm{HbA}_{1 \mathrm{c}}$. Nine patients with diabetes were taking insulin, and three were taking insulin and metformin. Metformin was stopped $\sim 6 \mathrm{wk}$ before the fat-loading test. Both diabetes and control groups were age, sex, body mass index (BMI), and sexual maturation matched. Clinical characteristics are shown in Table 1. The study was approved by the Institutional Review Board of the State University of New York Health Science Center (Brooklyn, NY). Each subject and legal guardian gave consent to participate.

Fat-loading tests and measurements. After overnight fasting and withholding of insulin injection (at least $12 \mathrm{~h}$ ), the subjects ingested a fat load over a period of $<5 \mathrm{~min}$. The fat load was a mixture of $350 \mathrm{~mL}$ of pasteurized heavy cream (G.A.F. Seelig, Inc., Woodside, NY), $15 \mathrm{~mL}$ of fat-free milk (G.A.F. Seelig), $15 \mathrm{~mL}$ of chocolate syrup (Hershey chocolate syrup, Hershey, PA), and 1 tablespoon of granulated sugar. It contained $117 \mathrm{~g}$ of fat $(70 \mathrm{~g}$ of saturated fat, $467 \mathrm{mg}$ of cholesterol), $41.5 \mathrm{~g}$ of carbohydrate, and $0.5 \mathrm{~g}$ of protein. It provided $1242 \mathrm{cal}$ : $86.4 \%$ from fat, $13.4 \%$ from carbohydrate, and $0.2 \%$ from protein. The fat load was modified from what was used by Patsch et al. (30) and was assigned to simulate the fat content of a high-fat, fast-food meal (28). Venous blood samples were obtained at $0,2,4$, and $6 \mathrm{~h}$ after the ingestion of the fat loads. The venous blood is processed to plasma, serum, and acidified plasma for glucose; lipid profile, C-peptide, and insulin; and PAI-1 and t-PA, respectively. The lipid profile included total cholesterol, triglyceride and HDL and LDL cholesterol determinations. The acidified plasma for t-PA was obtained by collecting 9 vol of blood in an ice-cold test tube that contained 1 vol of $0.13 \mathrm{M}$ sodium citrate, mixing, adding acetate (1 vol acetate: 2 vol citrated blood), placing on ice, and centrifuging within $30 \mathrm{~min}$ at $1500 \times \mathrm{g}$ for 5 min. Plasma was transferred to a new tube, and $20 \%$ acetic acid was added ( 0.05 vol of $20 \%$ acetic acid: 1 vol plasma) to acidify the plasma. All samples for PAI- 1 and t-PA were frozen and stored at $-70^{\circ} \mathrm{C}$ until assayed. PAI- 1 and t-PA activity measurements were performed using chromogenic assay (Spectrolyse; American Diagnostica Inc., Greenwich, CT). Total cholesterol, triglyceride, and HDL cholesterol concentrations were measured by standard colorimetric methods (Vitros; Ortho-Clinical Diagnostics, Inc., Rochester, NY) (31-33). LDL cholesterol concentrations were calculated using the Friedewald formula $[\mathrm{LDL}$ cholesterol $=$ total cholesterol $-(\mathrm{HDL}$ cholesterol + triglycerides/5)] (34). All samples for C-peptide and insulin were centrifuged at $4^{\circ} \mathrm{C}$. The sera were frozen and stored at $-20^{\circ} \mathrm{C}$ until assayed. C-peptide determinations were performed in duplicate by double-antibody RIA (C-peptide ${ }^{125} \mathrm{I}$ RIA kits; DiaSorin, Inc., Stillwater, MN), with a lower limit of detection of 0.2 $\mathrm{nmol} / \mathrm{L}$. Insulin determinations were performed in duplicate by RIA (Human Insulin Specific RIA kits; Linco Research, Inc., St. Charles, MO), with a lower limit of detection of $14 \mathrm{pmol} / \mathrm{L}$. Glucose concentrations were analyzed by a glucose oxidase method (Glucose Analyzer; Beckman Coulter, Inc., Brea, CA). Immunologic marker determinations (glutamic acid decarboxylase, islet cell autoantibodies, and insulin autoantibodies) were determined by RIA in the patients with diabetes and were all negative. $\mathrm{HbA}_{1 c}$ was measured by HPLC.

Statistics. Metabolic responses to the fat load were expressed as the area under the curve (AUC) calculated by trapezoidal estimation. Insulin resistance was estimated by the homeostasis model assessment (HOMA $=$ [fasting glucose $\times$ fasting insulin]/22.5) (35). Differences in age, BMI, $\mathrm{HbA}^{\text {lc }}$, fasting metabolic parameters, and AUC between the two groups were examined by Mann-Whitney tests because these parameters were not normally distributed

Table 1. Clinical characteristics of study groups

\begin{tabular}{lcc}
\hline & Diabetes $(n=12)$ & Control $(n=17)$ \\
\hline Age $(\mathrm{y})$ & $14.0 \pm 0.7$ & $13.2 \pm 0.5$ \\
Sex $(n ;$ female/male $)$ & $7 / 5$ & $9 / 8$ \\
BMI $\left(\mathrm{kg} / \mathrm{m}^{2}\right)$ & $32.7 \pm 1.1$ & $32.0 \pm 2.6$ \\
Tanner staging & & \\
2 & 1 & 3 \\
3 & 2 & 5 \\
4 & 4 & 7 \\
5 & 5 & 2 \\
Race & $92 \%$ black & $77 \%$ black \\
& $8 \%$ Asian & $23 \%$ Hispanic \\
\hline
\end{tabular}

Values are means \pm SEM. and our sample size was small. Differences in the metabolic responses between the two groups and across the four time points were also examined by repeated measures ANOVA. Both Mann-Whitney tests and repeated measures ANOVA yielded similar results for the differences of the metabolic parameters during the loading tests between the two groups. Only $p$ values from the MannWhitney tests were reported. Differences in sex and sexual maturation were examined by Fisher's exact tests. Correlations were evaluated, and multiple linear regression analyses were used when indicated. The statistical package for social sciences for Windows, version 10.5 (SPSS, Inc., Chicago, IL) was used for the statistical analyses. Significance was accepted at the level $p<$ 0.05 . Data are presented as mean \pm SEM.

\section{RESULTS}

Fasting state. Fasting PAI-1 activities were significantly greater in the diabetes group than in the control group. Fasting t-PA activities in the diabetes group were significantly lower than in the control group. Triglyceride was the only lipid parameter that was significantly different in the patients than in the control subjects. As expected, the fasting glucose and $\mathrm{HbA}_{1 \mathrm{c}}$ levels were significantly higher in the diabetes group when compared with the control group. The fasting C-peptide and insulin levels were also significantly greater in the diabetes group than in the control group. HOMA was greater in the patients with diabetes than in the control subjects (Table 2).

Postprandial state. PAI-1 AUC was significantly greater in the diabetes group than in the control group (Fig. 1A). t-PA AUC in the diabetes group was relatively lower than in the control group (Fig. 1B). Triglyceride responses in the diabetes group were significantly higher than in the control groups (Fig. 1C). Total cholesterol, HDL cholesterol, and LDL cholesterol AUCs did not differ between the two groups $[28.5 \pm 2.1$ versus $25.9 \pm 1.2 \mathrm{mmol} \cdot \mathrm{h}^{-1} \cdot \mathrm{L}^{-1}(p=\mathrm{NS}) ; 6.0 \pm 0.3$ versus 7.1 $\pm 0.4 \mathrm{mmol} \cdot \mathrm{h}^{-1} \cdot \mathrm{L}^{-1}(p=\mathrm{NS}) ; 16.9 \pm 2.0$ versus $14.8 \pm$ $1.4 \mathrm{mmol} \cdot \mathrm{h}^{-1} \cdot \mathrm{L}^{-1}(p=\mathrm{NS})$, respectively). As expected, glucose AUC was significantly higher in the diabetes group when compared with the control group (Fig. 1D). The Cpeptide and insulin AUCs were also significantly greater in the diabetes group than in the control group (Fig. $1 E$ and $F$, respectively).

When we compared changes of the metabolic parameters across the four time points, PAI- 1 activities decreased significantly $(p<0.0001)$. t-PA activities did not change. Triglycerides increased significantly $(p<0.0001)$. Total cholesterol levels increased significantly $(p<0.005)$, whereas HDL cho-

Table 2. Results of metabolic parameters at fasting state in study groups

\begin{tabular}{lccc}
\hline & $\begin{array}{c}\text { Diabetes } \\
(n=12)\end{array}$ & $\begin{array}{c}\text { Control } \\
(n=17)\end{array}$ & $p$ Values \\
\hline PAI-1 activity $(\mathrm{U} / \mathrm{mL})$ & $23.4 \pm 2.6$ & $12.9 \pm 2.0$ & 0.004 \\
t-PA activity $(\mathrm{U} / \mathrm{mL})$ & $0.8 \pm 0.3$ & $6.5 \pm 2.7$ & 0.001 \\
Triglyceride $(\mathrm{mmol} / \mathrm{L})$ & $1.5 \pm 0.2$ & $0.9 \pm 0.1$ & 0.05 \\
Total cholesterol $(\mathrm{mmol} / \mathrm{L})$ & $4.7 \pm 0.3$ & $4.2 \pm 0.2$ & $\mathrm{NS}$ \\
HDL cholesterol $(\mathrm{mmol} / \mathrm{L})$ & $1.1 \pm 0.1$ & $1.2 \pm 0.1$ & $\mathrm{NS}$ \\
LDL cholesterol $(\mathrm{mmol} / \mathrm{L})$ & $2.9 \pm 0.3$ & $2.6 \pm 0.2$ & $\mathrm{NS}$ \\
Glucose $(\mathrm{mmol} / \mathrm{L})$ & $9.2 \pm 1.3$ & $4.6 \pm 0.1$ & 0.007 \\
C-peptide $(\mathrm{nmol} / \mathrm{L})$ & $0.9 \pm 0.1$ & $0.7 \pm 0.04$ & 0.03 \\
Insulin $(\mathrm{pmol} / \mathrm{L})$ & $244.1 \pm 27.6$ & $151.8 \pm 19.8$ & 0.008 \\
HOMA $_{\text {HbA }}(\%)$ & $14.4 \pm 2.8$ & $4.6 \pm 0.7$ & 0.0001 \\
\hline
\end{tabular}

Values are expressed as means \pm SEM. 

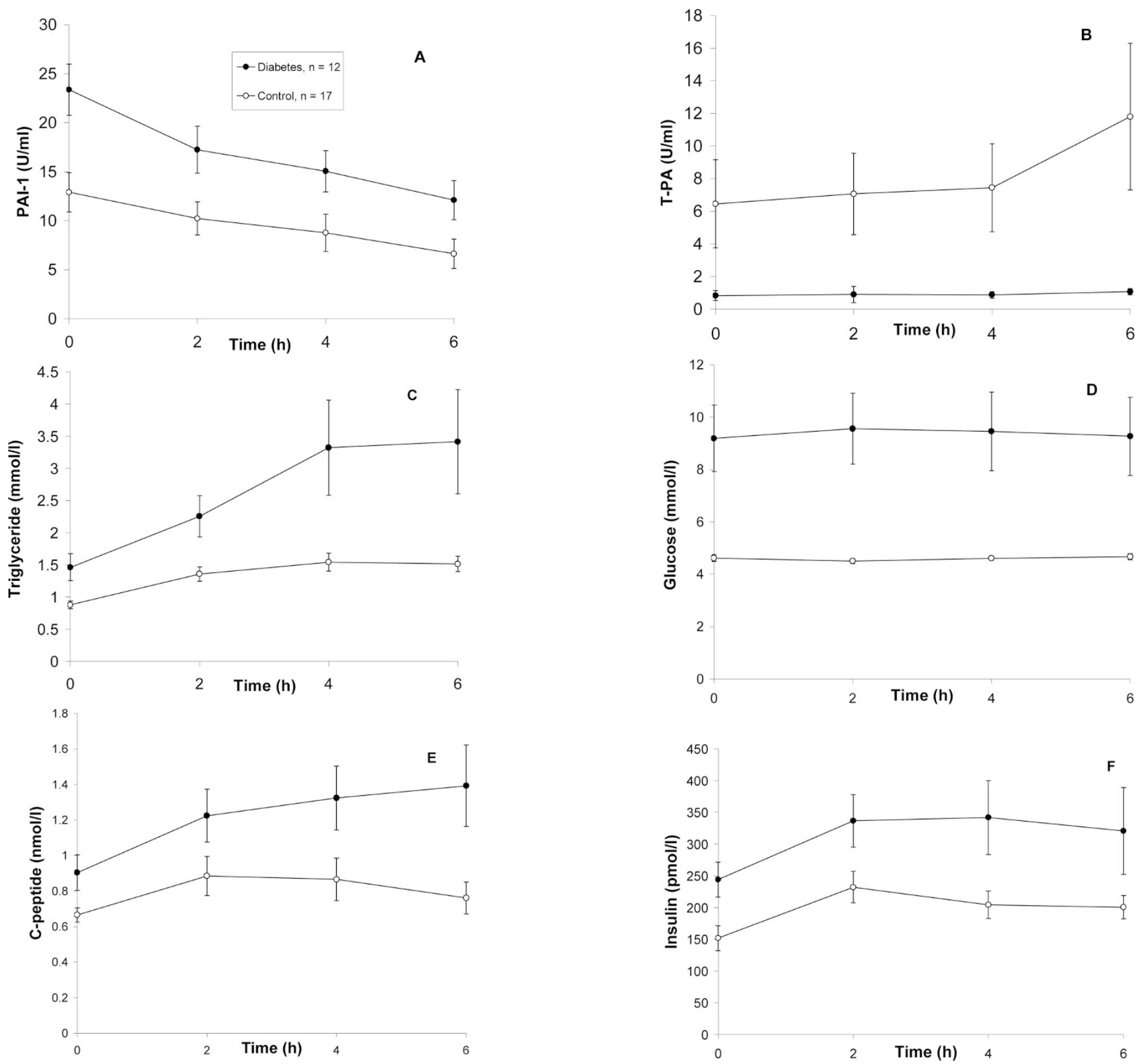

Figure 1. PAI-1, t-PA, triglyceride, glucose, C-peptide, and insulin responses during the fat-loading tests in diabetes $(n=12)$ and control $(n=17)$ groups; mean \pm SEM. (A) AUC of PAI-1 $\left(101.7 \pm 12.1\right.$ vs $\left.57.6 \pm 6.5 \mathrm{U} \cdot \mathrm{h}^{-1} \cdot \mathrm{mL}^{-1} ; p<0.003\right)$. (B) AUC of t-PA $\left(7.8 \pm 2.7 v s 58.3 \pm 19.3 \mathrm{U} \cdot \mathrm{h}^{-1} \cdot \mathrm{mL}^{-1}\right.$; $p=\mathrm{NS})$. (C) AUC of triglyceride $\left(15.7 \pm 2.9 v s 7.9 \pm 0.6 \mathrm{mmol} \cdot \mathrm{h}^{-1} \cdot \mathrm{L}^{-1} ; p<0.02\right)$. (D) AUC of glucose $\left(56.2 \pm 8.1 v s 27.6 \pm 0.5 \mathrm{mmol} \cdot \mathrm{h}^{-1} \cdot \mathrm{L}^{-1}\right.$; $p<0.01)$. (E) AUC of C-peptide $\left(7.3 \pm 0.8 v s 4.8 \pm 0.5 \mathrm{nmol} \cdot \mathrm{h}^{-1} \cdot \mathrm{L}^{-1} ; p<0.009\right)$. (F) AUC of insulin $\left(1865.0 \pm 263.3 v s 1167.2 \pm 74.0 \mathrm{pmol} \cdot \mathrm{h}^{-1}\right.$. $\left.\mathrm{L}^{-1} ; p<0.01\right)$.

lesterol levels decreased significantly $(p<0.04)$ and LDL cholesterol levels did not change. As expected, glucose levels did not change significantly. C-peptide and insulin levels increased significantly $(p<0.001$ and 0.006 , respectively).

Correlations. As a whole group, fasting PAI-1 activities were significantly correlated with fasting triglycerides $(r=$ $0.54, p<0.004)$, fasting insulin $(r=0.50, p<0.009)$, and HOMA $(r=0.70, p<0.001)$. Fasting t-PA activities were significantly correlated with fasting cholesterol levels $(r=$ $-0.51, p<0.009)$, fasting LDL cholesterol levels $(r=-0.52$, $p<0.008)$, and BMI $(r=-0.60, p<0.002)$. After multiple linear regression analyses, only correlation between fasting PAI-1 levels and HOMA remained significant. Postprandially, significant correlation was also found between PAI-1 AUCs and HOMA $(r=0.78, p<0.0001)$ after multiple linear regression analyses (Fig. 2).

\section{DISCUSSION}

This study shows for the first time that adolescents with type 2 diabetes have both fasting and postprandial unfavorable PAI-1 and t-PA activities when compared with nondiabetic 

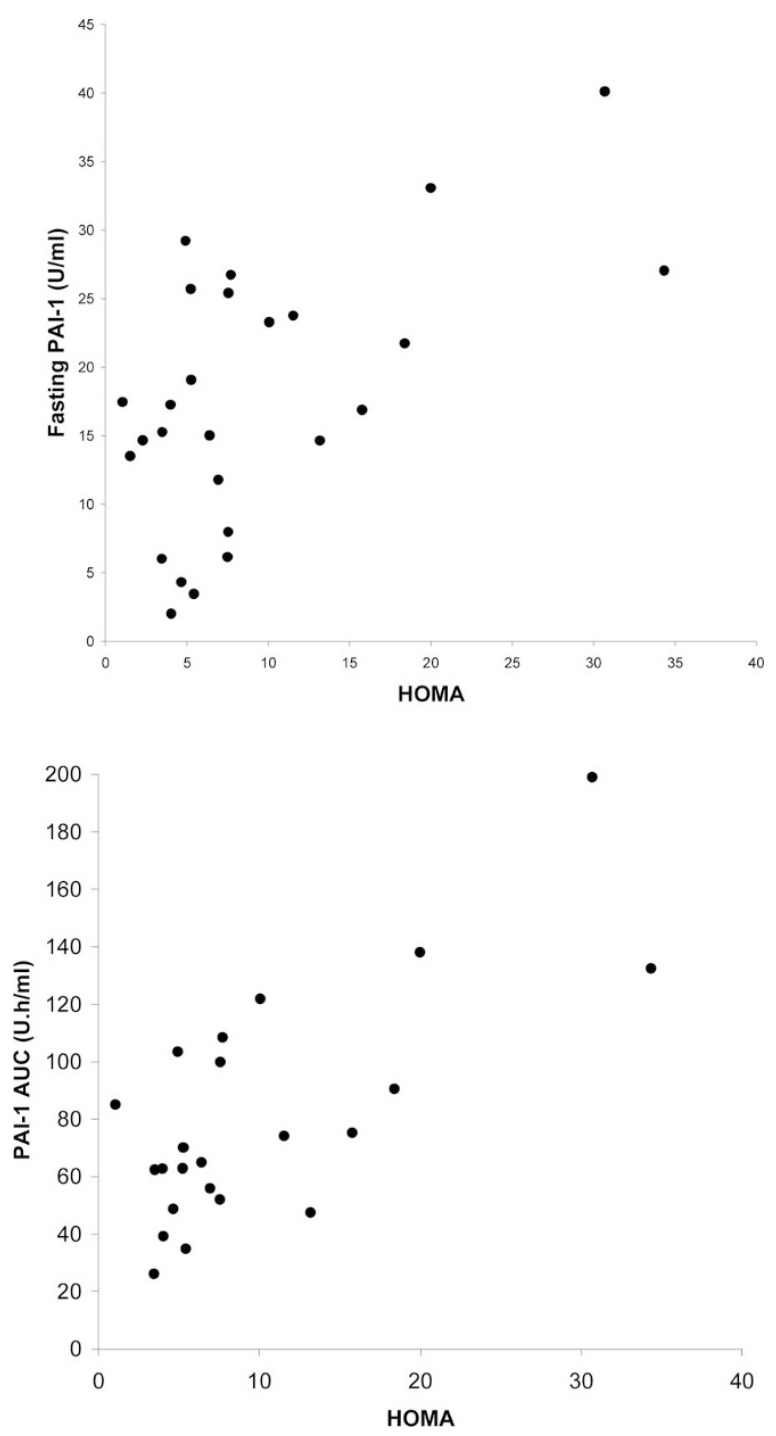

Figure 2. HOMA was significantly correlated with fasting PAI-1 $(r=0.70$, $p<0.001 ; n=26)$ and PAI-1 AUC $(r=0.78, p<0.0001 ; n=23)$.

adolescents who are equally obese and that these profiles are not negatively affected by an acute oral high-fat load. Because PAI-1 binds rapidly to t-PA and forms an inactive t-PA-PAI-1 complex, we measured PAI-1 and t-PA activities, rather than antigens. Increased PAI-1 and decreased t-PA activities are suggestive of reduced fibrinolytic activities and are unfavorable for CVD $(6,8,16,19,36)$. Patients who have diabetes and developed peripheral artery disease or late complications of diabetes showed a shift toward an antifibrinolytic pathway with diminished t-PA and increased PAI-1 antigen and activity $(12,17)$. Our adolescents with type 2 diabetes had mean duration of the disease of $7.1 \pm 2.5 \mathrm{mo}$; therefore, interference of any coexistent atherosclerosis as overt late complication of diabetes is very unlikely to affect the results of PAI- 1 and t-PA measurements.

At fasting and during postprandial states, PAI-1, triglyceride, glucose, C-peptide, and insulin levels were significantly higher in patients than in control subjects. Fasting t-PA activities were significantly lower in the patients than in the control subjects. Insulin resistance, represented by HOMA, was greater in the patients than that in the control subjects. A clustering of these cardiovascular risk factors, including increased PAI-1/decreased t-PA activities, hypertriglyceridemia, diabetes, and hyperinsulinemia, increases the risk for CVD.

The increased triglyceride levels during the fat-loading tests observed in our study are consistent with findings reported by others (37-39) and have been discussed previously (40). The relationship between elevated PAI-1, insulin resistance, and hypertriglyceridemia is established $(2,6,17,18,36,41)$ and is shown in our study. Therefore, elevated PAI-1 activities were anticipated during the fat-loading tests. On the contrary, the PAI-1 activities decreased significantly. Both increased and decreased PAI-1 activities after fat loads have been reported $(39,42-47)$. The difference in the postprandial PAI-1 responses has been explained by different genotypes of PAI-1, different fat types and content, and that PAI-1 has a circadian rhythm (PAI-1 concentrations decrease during the day) $(39,44,48,49)$. Whereas increase in triglycerides alone, as here in our study, or insulin alone (50) seems insufficient to increase PAI-1 concentrations, a combination of hypertriglyceridemia, hyperinsulinemia, and hyperglycemia can increase PAI-1 in blood in normal humans (51). Therefore, our results also support the hypothesis that several abnormal metabolic parameters are essential for the elevation of PAI-1 levels. In addition, chronic exposure to high fat loads may result differently. t-PA activities seemed unrelated to insulin resistance and were not affected by the fat-loading tests as reported previously (45). Nevertheless, the patients with type 2 diabetes had relatively lower t-PA activities than the control subjects throughout the fat-loading tests.

The differences in the PAI-1 levels in our diabetic and nondiabetic obese subjects, who had comparable BMIs, may be due to the difference in fat distribution (52-55). However, further investigation (e.g. computed tomography or magnetic resonance imaging to measure fat distribution) is needed to determine whether indeed our diabetic subjects have central fat distribution and our obese subjects have peripheral fat distribution. Furthermore, glycation, the result of hyperglycemia in the diabetic patients, may enhance the production of PAI-1 and attenuate that of t-PA $(22,56,57)$.

We conclude that elevated PAI-1 and diminished t-PA activities, suggestive of suppressed fibrinolysis, are present in our adolescents with type 2 diabetes, adding another risk factor for CVD, and high fat intake does not further negatively affect this suppressed fibrinolysis.

Acknowledgment. We thank the patients and their families for participation in this study and Dr. M.A. Banerji (Department of Medicine, SUNY Downstate) for assistance (C-peptide and insulin assays).

\section{REFERENCES}

1. American Diabetes Association 2003 Report of the expert committee on the diagnosis and classification of diabetes mellitus. Diabetes Care 26(suppl 1):S5-S20

2. Reusch JE 2002 Current concepts in insulin resistance, type 2 diabetes mellitus, and the metabolic syndrome. Am J Cardiol 90:19G-26G

3. Stamler J, Vaccaro O, Neaton JD, Wentworth D 1993 Diabetes, other risk factors, and 12-yr cardiovascular mortality for men screened in the Multiple Risk Factor Intervention Trial. Diabetes Care 16:434-444 
4. Eckel RH, Krauss RM 1998 American Heart Association call to action: obesity as a major risk factor for coronary heart disease. AHA Nutrition Committee. Circulation 97:2099-2100

5. American Association of Clinical Endocrinologists (AACE) 2000 AACE medical guideline for clinical practice for the diagnosis and treatment of dyslipidemia and prevention of atherogenesis. Endocr Pract 6:162-213

6. Kohler HP, Grant PJ 2000 Plasminogen-activator inhibitor type 1 and coronary artery disease. N Engl J Med 342:1792-1801

7. Sowers JR, Lester MA 1999 Diabetes and cardiovascular disease. Diabetes Care 22(suppl 3):C14-C20

8. Auwerx J, Bouillon R, Collen D, Geboers J 1988 Tissue-type plasminogen activator antigen and plasminogen activator inhibitor in diabetes mellitus. Arteriosclerosis $8: 68-72$

9. Jok1 R, Laimins M, Klein RL, Lyons TJ, Lopes-Virella MF, Colwell JA 1994 Platelet plasminogen activator 1 in patients with type II diabetes. Diabetes Care 17:818-823

10. Zeitler P, Thiede A, Muller HL 2001 Prospective study on plasma clotting parameters in diabetic children-no evidence for specific changes in coagulation system. Exp Clin Endocrinol Diabetes 109:146-150

11. Sudi KM, Gallistl S, Weinhandl G, Muntean W, Borkenstein MH 2000 Relationship between plasminogen activator inhibitor-1 antigen, leptin, and fat mass in obese children and adolescents. Metabolism 49:890-895

12. Lapolla A, Piarulli F, Sartore G, Rossetti C, Martana L, Carraro P, De Paoli M, Fedele D 2003 Peripheral artery disease in type 2 diabetes: the role of fibrinolysis. Thromb Haemost 89:91-96

13. Valle M, Gascon F, Martos R, Ruz FJ, Bermudo F, Rios R, Canete R 2000 Infantile obesity: a situation of atherothrombotic risk? Metabolism 49:672-675

14. Colwell JA 2000 Altered platelet function and fibrinolysis in diabetes mellitus. Endotrends 7:5-8

15. Juhan-Vague I, Roul C, Alessi MC, Ardissone JP, Heim M, Vague P 1989 Increased plasminogen activator inhibitor activity in non insulin dependent diabetic patientsrelationship with plasma insulin. Thromb Haemost 61:370-373

16. Rosito GA, D'Agostino RB, Massaro J, Lipinska I, Mittleman MA, Sutherland P, Wilson PW, Levy D, Muller JE, Tofler GH 2004 Association between obesity and a prothrombotic state: the Framingham Offspring Study. Thromb Haemost 91:683-689

17. Hernandez C, Chacon P, Garcia-Pascual L, Mesa J, Simo R 2000 Relationship between lipoprotein(a) phenotypes and plasminogen activator inhibitor type 1 in diabetic patients. Thromb Res 99:119-127

18. Juhan-Vague I, Vague P, Alessi MC, Badier C, Valadier J, Aillaud MF, Atlan C 1987 Relationships between plasma insulin, triglyceride, body mass index, and plasminogen activator inhibitor 1. Diabetes Metab 13:331-336

19. Glowinska B, Urban M, Koput A, Galar M 2003 New atherosclerosis risk factors in obese, hypertensive and diabetic children and adolescents. Atherosclerosis 167:275286

20. Cavallero E, Dachet C, Assadolahi F, Martin C, Navarro N, Ansquer JC, Corda C Foucher C, Juhan-Vague I, Jacotot B 2002 Micronized fenofibrate normalizes the enhanced lipidemic response to a fat load in patients with type 2 diabetes and optimal glucose control. Atherosclerosis 166:151-161

21. Romano M, Pomilio M, Vigneri S, Falco A, Chiesa PL, Chiarelli F, Davi G 2001 Endothelial perturbation in children and adolescents with type 1 diabetes: association with markers of the inflammatory reaction. Diabetes Care 24:1674-1678

22. Matsuo T, Kadowaki S, Okada K, Matsuo O 1990 Activity of tissue plasminogen activator and plasminogen activator inhibitor in noninsulin-dependent diabetes mellitus. J Diabet Complications 4:119-121

23. Ebbeling CB, Pawlak DB, Ludwig DS 2002 Childhood obesity: public-health crisis, common sense cure. Lancet 360:473-482

24. Ogden CL, Flegal KM, Carroll MD, Johnson CL 2002 Prevalence and trends in overweight among US children and adolescents, 1999-2000. JAMA 288:1728-1732

25. List JF, Levitsky LL 2002 The epidemic of type 2 diabetes in children and adolescents. Endocrinol Rounds 1:

26. Berenson GS, Wattigney WA, Tracy RE, Newman WP 3rd, Srinivasan SR, Webber LS, Dalferes ER Jr, Strong JP 1992 Atherosclerosis of the aorta and coronary arteries and cardiovascular risk factors in persons aged 6 to 30 years and studied at necropsy (The Bogulusa Heart Study). Am J Cardiol 70:851-858

27. Pathobiological Determinants of Atherosclerosis in Youth (PDAY) Research Group 1990 Relationship of atherosclerosis in young men to serum lipoprotein cholesterol concentrations and smoking. JAMA 264:3018-3024

28. Jones DR 2001 A Guide to Nutrition and Dietary Exchange Values for Fast-Food Frankling Publishing Incorporated, Indianapolis, pp 75-78

29. Diabetes Control and Complication Trial 1986 Design and methodologic considerations for the feasibility phase. Diabetes 35:530-545

30. Patsch JR, Karlin JB, Scott LW, Smith LC, Gotto AM Jr 1983 Inverse relationship between blood levels of high density lipoprotein subfraction 2 and magnitude of postprandial lipemia. Proc Natl Acad Sci USA 80:1449-1453

31. Allain CC, Poon LS, Chan CS, Richmond W, Fu PC 1974 Enzymatic determination of total serum cholesterol. Clin Chem 20:470-475

32. Spayd RW, Bruschi B, Burdick BA, Dappen GM, Eikenberry JN, Esders TW, Figueras J, Goodhue CT, LaRossa DD, Nelson RW, Rand RN, Wu TW 1978 Multilayer film elements for clinical analysis. Clin Chem 24:1348-1350

33. Warnick GR, Benderson J, Albers JJ 1983 Dextran sulfate- $\mathrm{Mg}^{+2}$ precipitation procedure for quantitation of high-density lipoprotein cholesterol. Select Methods Clin Chem 10:91-99
34. Friedewald WT, Levy RI, Fredrickson DS 1972 Estimation of the concentration of low-density lipoprotein cholesterol in plasma, without use of the preparative ultracentrifuge. Clin Chem 18:499-502

35. Matthews DR, Hosker JP, Rudenski AS, Naylor BA, Treacher DF, Turner RC 1985 Homeostasis model assessment: insulin resistance and $\beta$-cell function from fasting plasma glucose and insulin concentrations in man. Diabetologia 28:412-419

36. Bastard JP, Pieroni L, Hainque B 2000 Relationship between plasma plasminogen activator inhibitor 1 and insulin resistance. Diabetes Metab Res Rev 16:192-201

37. Lewis GF, O'Meara NM, Soltys PA, Blackman JD, Iverius PH, Pugh WL, Getz GS, Polonsky KS 1991 Fasting hypertriglyceridemia in noninsulin-dependent diabetes mellitus is an important predictor of postprandial lipid and lipoprotein abnormalities. J Clin Endocrinol Metab 72:934-944

38. Moreno LA, Quintela I, Fleta J, Sarria A, Roda L, Giner A, Bueno M 2001 Postprandial triglyceridemia in obese and non-obese adolescents. Importance of body composition and fat distribution. J Pediatr Endocrinol Metab 14:193-202

39. Byrne CD, Wareham NJ, Martensz ND, Humphries SE, Metcalfe JC, Grainger DJ 1998 Increased PAI activity and PAI-1 antigen occurring with an oral fat load: associations with PAI-1 genotype and plasma active TGF- $\beta$ levels. Atherosclerosis 140:45-53

40. Umpaichitra V, Banerji MA, Castells S 2004 Postprandial hyperlipidemia after a fat loading test in minority adolescents with type 2 diabetes mellitus and obesity. J Pediatr Endocrinol Metab 17:853-864

41. Chadarevian R, Bruckert E, Dejager S, Presberg P, Turpin G 1999 Relationship between triglycerides and factor VIIc and plasminogen activator inhibitor type-1: lack of threshold value. Thromb Res 96:175-182

42. Tholstrup T, Marckmann P, Hermansen J, Holmer G, Sandstrom B 1999 Effect of modified dairy fat on fasting and postprandial haemostatic variables in healthy young men. Br J Nutr 82:105-113

43. Tholstrup T, Miller GJ, Bysted A, Sanstrom B 2003 Effect of individual dietary fatty acids on postprandial activation of blood coagulation factor VII and fibrinolysis in healthy young men. Am J Clin Nutr 77:1125-1132

44. Sanders TA, de Grassi T, Acharya J, Miller GJ, Humphries SE 2004 Postprandial variations in fibrinolytic activity in middle-aged men are modulated by plasminogen activator inhibitor I 4G-675/5G genotype but not by the fat content of a meal. Am J Clin Nutr 79:577-581

45. Salomaa V, Rasi V, Pekkanen J, Jauhiainen M, Vahtera E, Pietinen P, Korhonen H, Kuulasmaa K, Ehnholm C 1993 The effects of saturated fat and n-6 polyunsaturated fat on post prandial lipemia and hemostatic activity. Atherosclerosis 103:1-11

46. Tholstrup T, Andreasen K, Sandstrom B 1996 Acute effect of high-fat meals rich in either stearic or myristic acid on hemostatic factors in healthy young men. Am J Clin Nutr 64:168-176

47. Nordoy A, Bonaa KH, Sandset PM, Hansen JB, Nilsen H 2000 Effect of $\omega$-3 fatty acids and simvastatin on hemostatic risk factors and postprandial hyperlipemia in patients with combined hyperlipemia. Arterioscler Thromb Vasc Biol 20:259-265

48. Andreotti F, Davies GJ, Hackett DR, Khan MI, De Bart AC, Aber VR, Maseri A, Kluft C 1988 Major circadian fluctuations in fibrinolytic factors and possible relevance to time of onset of myocardial infarction, sudden cardiac death and stroke. Am J Cardiol 62:635-637

49. Wiman B, Hamsten A 1990 The fibrinolytic enzyme system and its role in the etiology of thromboembolic disease. Semin Thromb Haemost 16:207-216

50. Potter Van Loon BJ, de Bart AC, Radder JK, Frouch M, Kluft C, Menders AE 1990 Acute exogenous hyperinsulinemia does not result in elevation of plasma plasminogen activator inhibitor 1 (PAI-1) in human. Fibrinolysis 4:93-94

51. Calles-Escandon J, Mirza SA, Sobel BE, Schneider DJ 1998 Induction of hyperinsulinemia combined with hyperglycemia and hypertriglyceridemia increases plasminogen activator inhibitor 1 in blood in normal human subjects. Diabetes 47:290-293

52. Mertens I, Van der Planken M, Corthouts B, Wauters M, Peiffer F, De Leeuw I, Van Gaal L 2001 Visceral fat is a determinant of PAI-1 activity in diabetic and nondiabetic overweight and obese women. Horm Metab Res 33:602-607

53. Giltay EJ, Elbers JM, Gooren LJ, Emeis JJ, Kooistra T, Asscheman H, Stehouwer CD 1998 Visceral fat accumulation is an important determinant of PAI-1 levels in young, nonobese men and women: modulation by cross-sex hormone administration. Arterioscler Thromb Vasc Biol 18:1716-1722

54. Aso Y, Matsumoto S, Fujiwara Y, Tayama K, Inukai T, Takemura Y 2002 Impaired fibrinolytic compensation for hypercoagulability in obese patients with type 2 diabetes: association with increased plasminogen activator inhibitor-1. Metabolism 51:471-476

55. Alessi MC, Peiretti F, Morange P, Henry M, Nalbone G, Juhan-Vague I 1997 Production of plasminogen activator inhibitor 1 by human adipose tissue: possible link between visceral fat accumulation and vascular disease. Diabetes 46:860-867

56. Zhang J, Ren S, Shen GX 2000 Glycation amplifies lipoprotein(a)-induced alterations in the generation of fibrinolytic regulators from human vascular endothelial cells. Atherosclerosis 150:299-308

57. Ito Y, Okeda T, Sato Y, Ito M, Sakata T 1996 Plasminogen activator inhibitor-1 in nonobese subjects with non-insulin-dependent diabetes mellitus. Proc Soc Exp Biol Med 211:287-291 